\title{
Postnatal care of newborns in the family context: an integrative review
}

\author{
Cuidado pós-natal de recém-nascidos no contexto da família: revisão integrativa \\ Atención posnatal de los recién nacidos en el contexto familiar: revisión integrativa
}

Fernanda Garcia Bezerra Góes' ORCID: 0000-0003-3894-3998

Maria da Anunciação Silva' ORCID: 0000-0002-0069-5100

Andressa Silva Torres dos Santos ORCID: 0000-0001-7142-911X

Brenda Freitas Pontes' ORCID: 0000-0001-9246-4395

Ingrid Lucchese' ORCID: 0000-0001-7839-698X Mariana Tavares da Silva' ORCID: 0000-0002-8862-2474

'Universidade Federal Fluminense. Rio das Ostras, Rio de Janeiro, Brazil.

How to cite this article: Góes FGB, Silva MA, Santos AST, Pontes BF, Lucchese I, Silva MT. Postnatal care of newborns in the family context: an integrative review. Rev Bras Enferm. 2020;73(Suppl 4):e20190454. doi: http://dx.doi.org/10.1590/0034-7167-2019-0454

\section{Corresponding author:}

Fernanda Garcia Bezerra Góes E-mail: ferbezerra@gmail.com

EDITOR IN CHIEF: Dulce Barbosa ASSOCIATE EDITOR: Margarida Vieira

Submission: 10-28-2019

\section{ABSTRACT}

Objective: to analyze the postnatal care practices of newborns in the family context from the scientific literature. Methods: the searches of the integrative literature review were carried out in the Latin American and Caribbean Literature in Health Sciences (LILACS), Nursing Database (BDENF), Scientific Electronic Library Online (SciELO), and U.S. National Library of Medicine (PubMed) databases. Results: sixteen studies composed the final sample and, from these, two analytical categories emerged: Practices and doubts of families in postnatal care of newborns; and Best practices in postnatal care of newborns. Final considerations: several cultural practices of families differ from scientific recommendations, which can generate risks to the health of newborns. Therefore, it is essential to consolidate educational programs with family members, to improve the quality of care offered and to reduce preventable neonatal deaths in different socio-family contexts.

Descriptors: Neonatal Nursing; Infant Care; Newborn; Postnatal Care; Family.

\section{RESUMO}

Objetivo: analisar as práticas de cuidado pós-natal de recém-nascidos no contexto da família a partir da literatura científica. Métodos: revisão integrativa da literatura, cujas buscas foram realizadas nos recursos informacionais Literatura Latino-Americana e do Caribe em Ciências da Saúde (LILACS), Base de Dados de Enfermagem (BDENF), Scientific Eletronic Library Online (SciELO) e U.S. National Library of Medicine (PubMed). Resultados: 16 estudos compuseram a amostra final e, a partir desses, duas categorias analíticas foram originadas: Práticas e dúvidas de famílias no cuidado pós-natal de recém-nascidos; e Boas práticas no cuidado pós-natal de recém-nascidos. Considerações finais: diversas práticas culturais das famílias divergem das recomendações científicas, o que pode gerar riscos à saúde dos recém-nascidos. Logo, é essencial a consolidação de programas educativos junto aos familiares, para melhorias na qualidade dos cuidados ofertados e redução de mortes neonatais evitáveis em diferentes contextos sociofamiliares.

Descritores: Enfermagem Neonatal; Cuidado do Lactente; Recém-Nascido; Cuidado PósNatal; Família.

\section{RESUMEN}

Objetivo: analizar las prácticas de atención posnatal de los recién nacidos en el contexto familiar a partir de la literatura científica. Métodos: revisión bibliográfica integradora, cuyas búsquedas se realizaron en los recursos de información Literatura Latinoamericana y Caribeña en Ciencias de la Salud (LILACS), Base de Datos de Enfermería (BDENF), Scientific Eletronic Library Online (SciELO) y U.S. National Library of Medicine (PubMed). Resultados: 16 estudios constituyeron la muestra final y, a partir de estos, se originaron dos categorías analíticas: prácticas y dudas de las familias en el cuidado posnatal de los recién nacidos; y Buenas prácticas en atención posnatal para recién nacidos. Consideraciones finales: varias prácticas culturales de las familias difieren de las recomendaciones científicas, lo que puede generar riesgos para la salud de los recién nacidos. Por lo tanto, es esencial consolidar los programas educativos con los miembros de la familia, para mejorar la calidad de la atención ofrecida y reducir las muertes neonatales prevenibles en diferentes contextos sociales y familiares.

Descriptores: Enfermería Neonatal; Cuidado del Niño; Recién Nacido; Atención Posnatal; Familia. 


\section{INTRODUCTION}

In 2015, at the United Nations General Assembly, 17 Sustainable Development Goals (SDGs) were established for 2030 to continue the work begun 15 years earlier through the Millennium Development Goals (MDGs). These global goals aim to guarantee healthy lives and promote well-being for all, some of which refer to neonatal health, directly or indirectly. As an example, goal two, referring to the third SDG, proposes the end of preventable deaths of newborns (NB) and reduction of neonatal mortality (from 0 to 27 days of life) to at least 12 in every 1,000 live births in all countries ${ }^{(1)}$. However, progress in reducing these deaths has been slow, as approximately three million NBs still die every year worldwide(2).

However, the quality of care offered to NBs immediately after birth and in the first days of life has priority importance for their survival and for their healthy and harmonious development. It is, therefore, one of the global challenges to be overcome so that mortality rates in this period are significantly reduced worldwide ${ }^{(1-2)}$. In this sense, it is estimated that the increase in coverage and quality of preconception, prenatal, intrapartum, and postnatal interventions can prevent $71 \%$ of neonatal deaths worldwide every year, especially in low and middle income countries, including the promotion of basic preventive care in the family and community ${ }^{(3)}$.

Actions aimed at reducing health inequalities and improving the quality of care provided are essential elements for prevention neonatal deaths ${ }^{(1)}$. Following this line of reasoning, a systematic review of available interventions to reduce preventable deaths in NBs identified that basic care such as exclusive breastfeeding, adequate hygiene, including umbilical stump and heat supply are preventive practices. These practices are simple and capable of significantly contributing to reducing neonatal mortality ${ }^{(3)}$.

On the other hand, erroneous care can cause real damage to the NBs' health, affecting their survival, especially in the first week of life. This fact reinforces the need to value care in the context of the family and the community, as well as adequate guidance and monitoring by health professionals, especially nurses, regarding safe postnatal care ${ }^{(4)}$.

Many care practices emerge from the life context of people related to maternal and family biopsychosociocultural spheres ${ }^{(5)}$. They sometimes converge or not with the best scientific evidence. Therefore, it is recognized that guidelines on care, developed by the health team, occur in a cross-sectional way since prenatal care, going through the transition process from motherhood to home, in addition to subsequent consultations in primary care and home visits.

However, data on home care practices of NBs developed by families, in different social and cultural contexts, which support the development of comprehensive educational programs by health professionals, are dispersed in the scientific literature. Therefore, it is necessary to add in a single study a synthesis of these cultural practices in the post-discharge period, given the importance of family members taking care of their babies at home with quality, autonomy and safety. This knowledge implies construction of educational strategies based on real educational demands of families and on best evidence on the topic, thus aiming at a better quality of care offered as well as reduction of neonatal morbidity and mortality from preventable causes.

\section{OBJECTIVE}

To analyze the postnatal care practices of NBs in the family context from the scientific literature.

\section{METHODS}

This integrative literature review was performed based on the six steps provided for in the method ${ }^{(6)}$. After identifying the topic, the research question was formulated using the PICo strategy (P Population; I- Interest; Co - Context). This occurred in consultation with the Health Sciences Descriptors created by the Latin American \& Caribbean Center for Health Sciences Information (DeCS/BIREME) and the Medical Subject Headings (MeSH terms) of the U.S. National Library of Medicine, as shown in Chart 1. It is noteworthy that as it is not an exact descriptor, the term "home" was used as a word during searches in Portuguese, Spanish, and English.

Chart 1 - PICo strategy, DeCS in Portuguese and Spanish, and MeSH terms, 2019

\begin{tabular}{|c|c|c|c|c|c|}
\hline \multicolumn{3}{|c|}{ PICo Strategy } & \multirow{2}{*}{$\begin{array}{c}\text { DeCS in } \\
\text { Portuguese }\end{array}$} & \multirow{2}{*}{$\begin{array}{l}\text { DeCS in } \\
\text { Spanish }\end{array}$} & \multirow{2}{*}{$\begin{array}{l}\text { MeSH } \\
\text { terms }\end{array}$} \\
\hline PICo & Variables & Components & & & \\
\hline $\mathbf{P}$ & Population & Newborn & $\begin{array}{l}\text { Recém- } \\
\text { Nascido }\end{array}$ & $\begin{array}{l}\text { Recién } \\
\text { Nacido }\end{array}$ & Newborn \\
\hline \multirow{3}{*}{ I } & \multirow{3}{*}{ Interest } & \multirow{3}{*}{ Care } & $\begin{array}{c}\text { Cuidado da } \\
\text { Criança }\end{array}$ & $\begin{array}{l}\text { Cuidado } \\
\text { del Niño }\end{array}$ & $\begin{array}{l}\text { Infant } \\
\text { Care }\end{array}$ \\
\hline & & & $\begin{array}{l}\text { Cuidado do } \\
\text { Lactente }\end{array}$ & $\begin{array}{c}\text { Cuidado } \\
\text { del } \\
\text { Lactante }\end{array}$ & $\begin{array}{l}\text { Child } \\
\text { Care }\end{array}$ \\
\hline & & & $\begin{array}{l}\text { Cuidado Pós- } \\
\text { Natal }\end{array}$ & $\begin{array}{l}\text { Atención } \\
\text { Posnatal }\end{array}$ & $\begin{array}{l}\text { Postnatal } \\
\text { Care }\end{array}$ \\
\hline \multirow[b]{2}{*}{ Co } & \multirow[b]{2}{*}{ Context } & \multirow[b]{2}{*}{ Family } & Família & Familia & Family \\
\hline & & & $\begin{array}{l}\text { Domicílio } \\
\text { (palavra) }\end{array}$ & $\begin{array}{l}\text { Domicilio } \\
\text { (palabra) }\end{array}$ & $\begin{array}{l}\text { Home } \\
\text { (word) }\end{array}$ \\
\hline
\end{tabular}

Therefore, the research question that conducted the study was: what are the postnatal care practices for NBs in the family context described in the scientific literature? Therefore, the controlled descriptors were used in Portuguese, Spanish, and English: "Recém-Nascido/Recién Nacido/Newborn"; "Cuidado da Criança/Cuidado del Niño/Infant Care"; "Cuidado do Lactente/ Cuidado del Lactante/Child Care"; "Cuidado Pós-Natal/Atención Posnatal/Postnatal Care"; "Família/Familia/Family"; and "Domicílio/ Domicilio/Home" as words. They were the search words.

For consultations, an advanced search form was used in different information resources, respecting their specificities, such as: Latin American \& Caribbean Literature in Health Sciences (Literatura Latino-Americana e do Caribe em Ciências da Saúde, abbreviated LILACS), Nursing Database (BDENF), Scientific Electronic Library Online (SciELO), and U.S. National Library of Medicine (PubMed).

The searches, carried out in the second half of 2018, occurred with the words associated with each other, through the Boolean operator "AND" in pairs and, in the specific case of PubMed, in trio, using all possible combinations, thus aiming at obtaining publications that were most related to the central topic of the research. For this purpose, the combinations were made respecting the singularities of each resource, therefore, consultations were 
performed in Portuguese at LILACS and BDENF, and "Subject descriptor"was used in the field. At SciELO, searches were carried out in Portuguese, English and Spanish, and "All Indexes" was used in the field. At PubMed, searches were performed in English, and "MeSH Terms" was used in the field. When associations included the terms "Domicilio/Domicilio/Home" at LILACS and BDENF, the field "Words" was used, and at PubMed, "Text Word" for these words specifically, however, at LILACS, it remained in "All Indexes".

Through the results of these search strategies, text skimming of titles and abstracts was initiated for the previous selection of publications potentially eligible for the study in view of adherence to the topic. Subsequently, the following inclusion criteria were applied to previously selected publications: publications available online and in full; with search results in Portuguese, Spanish and English; produced from January 2008 to October 2018 , aiming to obtain recently produced publications on the offer of postnatal care to NBs in the family. The exclusion criteria were: duplicate publications (duplicate articles were considered only once); experience reports; literature reviews (with the exception of systematics); reflection articles; editorials; letters and productions not related to the purpose of the study. We chose to use these criteria to select studies that would answer the research question in this review with greater specificity.

The final selection of articles, in order to ensure consistency and validation of the findings, was reviewed by peers (two researchers), by re-reading each of the manuscripts. Subsequently, an analytical framework was built for data analysis, which made it possible to synthesize and group the key information from the studies. The interpretation of relevant information on the postnatal care practices of NBs developed in the family context was used through categorization of findings.

\section{RESULTS}

The different intersections of the words generated a universe of 5,622 studies. However, with a thorough reading of the titles and abstracts and application of three initial criteria, year of publication, language and approximation to the purpose of the study, only 238 publications were previously selected. With the application of the other inclusion and exclusion criteria such as duplicity, availability and type of production, 48 articles remained, which were read in full. Of these, 32 manuscripts were excluded because they did not specifically answer the research question. Thus, 16 studies made up the final sample, as they specifically dealt with postnatal care practices of NBs in the family context (Figure 1). Therefore, Chart 2 presents the variables, year, title, authors, journal and objective(s) of publications.

Of the 16 articles (100\%) selected, 03 (18.8\%) were published in each year of 2014, 2013 and 2011; 02 (12.5\%) in 2012 and 2009, with only 01 (6.3\%) publication/year in 2017, 2016 and 2008. No publications were found in the years 2010, 2015 and 2018.

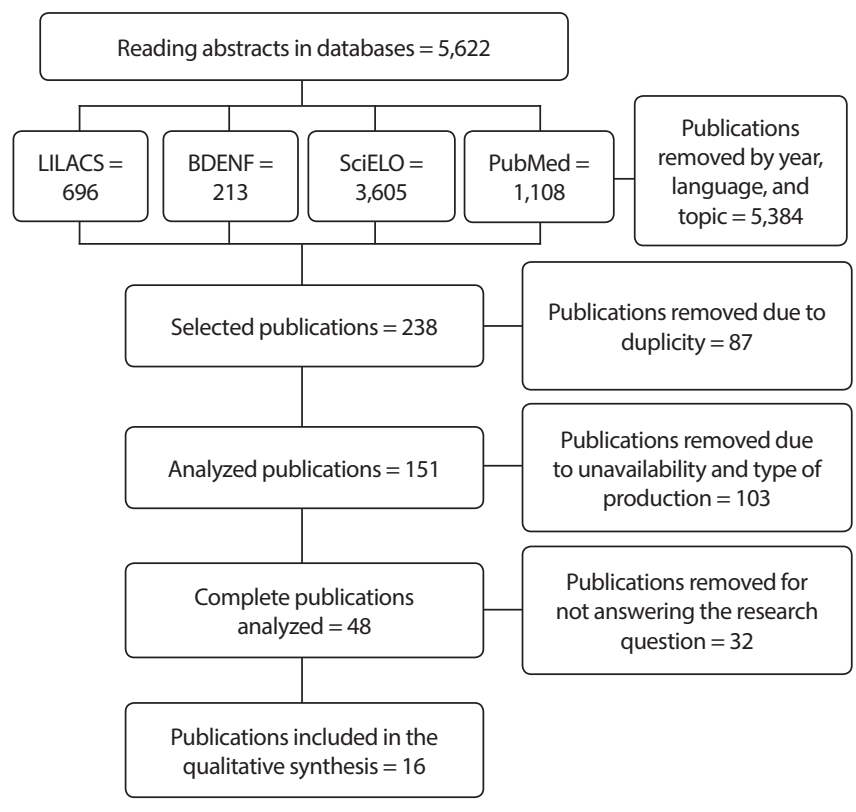

Figure 1 - Flowchart of article selection in information resources, 2018

Chart 2 - Characterization of articles selected for analysis, according to title, year, country, outlining/number of participants, authors and objective(s), 2019

\begin{tabular}{|c|c|c|c|c|}
\hline Title & $\begin{array}{l}\text { Year/ } \\
\text { Country }\end{array}$ & $\begin{array}{l}\text { Outlining/number of } \\
\text { participants }\end{array}$ & $\begin{array}{l}\text { Data collection } \\
\text { technique/ } \\
\text { Intervention } \\
\end{array}$ & Objective(s) \\
\hline $\begin{array}{l}\text { A1 - Influência geracional } \\
\text { familiar no banho do recém- } \\
\text { nascido e prevenção de } \\
\text { onfalites }^{(7)}\end{array}$ & $\begin{array}{l}2017 \\
\text { Brazil }\end{array}$ & $\begin{array}{l}\text { Qualitative/ } \\
\text { Ten mothers and } 19 \text { family } \\
\text { members }\end{array}$ & $\begin{array}{l}\text { Semi-structured interview } \\
\text { and observation } \\
\text { participant/ } \\
\text { Without intervention }\end{array}$ & $\begin{array}{l}\text { To know how generational interrelations } \\
\text { interfere with NB bathing and preventing } \\
\text { omphalitis. }\end{array}$ \\
\hline $\begin{array}{l}\text { A2 - Postnatal and } \\
\text { neonatal care after home } \\
\text { birth: a community-based } \\
\text { study in Nepal }{ }^{(8)}\end{array}$ & $\begin{array}{l}2016 \\
\text { Nepal }\end{array}$ & $\begin{array}{c}\text { Prospective/ } \\
92 \text { puerperal women }\end{array}$ & $\begin{array}{c}\text { Structured } \\
\text { questionnaire/ } \\
\text { Without intervention }\end{array}$ & $\begin{array}{l}\text { To investigate the postnatal and neonatal } \\
\text { care practices of women who gave birth at } \\
\text { home in a central mountain district in Nepal. }\end{array}$ \\
\hline $\begin{array}{l}\text { A3 - Breast feeding among } \\
\text { Brazilian adolescents: } \\
\text { practice and needs }{ }^{(9)}\end{array}$ & $\begin{array}{l}2014 \\
\text { Brazil }\end{array}$ & $\begin{array}{l}\text { Quanti-qualitative/ } 229 \\
\text { adolescent mothers in the } \\
\text { first stage and } 10 \text { adolescent } \\
\text { mothers in the second stage }\end{array}$ & $\begin{array}{c}\text { Interview/ } \\
\text { Without intervention }\end{array}$ & $\begin{array}{l}\text { To characterize breastfeeding practices } \\
\text { among Brazilian adolescents and identify } \\
\text { their breastfeeding needs. }\end{array}$ \\
\hline $\begin{array}{l}\text { A4 - Newborn care } \\
\text { practices and home-based } \\
\text { postnatal newborn care } \\
\text { program - Mewat, Haryana, } \\
\text { India, } 2013^{(10)}\end{array}$ & $\begin{array}{l}2014 \\
\text { India }\end{array}$ & $\begin{array}{l}\text { Quantitative - cross-sectional/ } \\
320 \text { mothers, } 61 \text { accredited } \\
\text { social health activists and } \\
\text { observation of } 19 \text { home visits }\end{array}$ & $\begin{array}{c}\text { Semi-structured } \\
\text { interview/ } \\
\text { Without intervention }\end{array}$ & $\begin{array}{l}\text { To study NB care practices among mothers from } \\
\text { Mewat, Haryana, with high neonatal mortality; } \\
\text { To determine risk factors for unsafe practices; To } \\
\text { describe the knowledge and skills of accredited } \\
\text { social health activists during home visits. }\end{array}$ \\
\hline
\end{tabular}

To be continued 


\begin{tabular}{|c|c|c|c|c|}
\hline Title & $\begin{array}{l}\text { Year/ } \\
\text { Country }\end{array}$ & $\begin{array}{l}\text { Outlining/number of } \\
\text { participants }\end{array}$ & $\begin{array}{l}\text { Data collection } \\
\text { technique/ } \\
\text { Intervention }\end{array}$ & Objective(s) \\
\hline $\begin{array}{l}\text { A5 - Postnatal experiences } \\
\text { and support needs of first- } \\
\text { time mothers in Singapore: } \\
\text { a descriptive qualitative } \\
\text { study }^{(11)}\end{array}$ & $\begin{array}{c}2014 \\
\text { Singapore }\end{array}$ & $\begin{array}{l}\text { Qualitative/ } \\
13 \text { primiparous mothers }\end{array}$ & $\begin{array}{l}\text { Semi-structured } \\
\text { interview/ } \\
\text { Without intervention }\end{array}$ & $\begin{array}{l}\text { To explore first-time mothers' first postnatal } \\
\text { experiences and support needs after the } \\
\text { hospital in Singapore. }\end{array}$ \\
\hline $\begin{array}{l}\text { A6 - Adopción de prácticas } \\
\text { saludables en puérperas } \\
\text { adolescentes }^{(12)}\end{array}$ & $\begin{array}{c}2013 \\
\text { Colombia }\end{array}$ & $\begin{array}{l}\text { Quantitative- Prospective/ } \\
251 \text { adolescent mothers and } \\
\text { their NBs }\end{array}$ & $\begin{array}{l}\text { Questionnaire/ } \\
\text { Without intervention }\end{array}$ & $\begin{array}{l}\text { To implement the Home Care Program for } \\
\text { adolescent mothers who were admitted to } \\
\text { Hospital Universitário ESE Erasmo Meoz and } \\
\text { their NBs. }\end{array}$ \\
\hline $\begin{array}{l}\text { A7 - Práticas de cuidado do } \\
\text { recém-nascido baseadas } \\
\text { no contexto de vida da } \\
\text { puérpera }^{(5)}\end{array}$ & $\begin{array}{l}2013 \\
\text { Brazil }\end{array}$ & $\begin{array}{c}\text { Qualitative/ } \\
20 \text { puerperal women }\end{array}$ & $\begin{array}{l}\text { Semi-structured } \\
\text { interview/ } \\
\text { Without intervention }\end{array}$ & $\begin{array}{l}\text { To verify care practices of NBs arising from the } \\
\text { context of life of puerperal women users of a } \\
\text { Basic Health Unit in the city of Rio Claro, SP. }\end{array}$ \\
\hline $\begin{array}{l}\text { A8 - Popular Knowledge } \\
\text { in Care of the Newborn } \\
\text { With Focus on Health } \\
\text { Promotion }^{(13)}\end{array}$ & $\begin{array}{l}2013 \\
\text { Brazil }\end{array}$ & $\begin{array}{l}\text { Qualitative/ } \\
15 \text { mothers of NBs }\end{array}$ & $\begin{array}{l}\text { Semi-structured } \\
\text { interview and form/ } \\
\text { Without intervention }\end{array}$ & $\begin{array}{l}\text { To verify the influence of popular knowledge } \\
\text { on NB care, with a focus on promoting } \\
\text { children's health }\end{array}$ \\
\hline $\begin{array}{l}\text { A9 - Dificuldade dos pais no } \\
\text { cuidar do recém-nascido }\end{array}$ & $\begin{array}{c}2012 \\
\text { Portugal }\end{array}$ & $\begin{array}{l}\text { Quantitative - Non- } \\
\text { experimental, cross-sectional/ } \\
88 \text { fathers/mothers }\end{array}$ & $\begin{array}{l}\text { Questionnaire/ } \\
\text { Without intervention }\end{array}$ & $\begin{array}{l}\text { To determine the socio-demographic } \\
\text { characteristics of parents of NBs at one month } \\
\text { of age and identify the parents' difficulties in } \\
\text { caring for NBs during the first month of life. }\end{array}$ \\
\hline $\begin{array}{l}\text { A10 - Influência } \\
\text { intergeracional no cuidado } \\
\text { do coto umbilical do recém- } \\
\text { nascido }^{(15)}\end{array}$ & $\begin{array}{l}2012 \\
\text { Brazil }\end{array}$ & $\begin{array}{c}\text { Qualitative/ } 29 \text { subjects, } 10 \text { of } \\
\text { them recently given birth and } \\
19 \text { family caregivers }\end{array}$ & $\begin{array}{l}\text { Semi-structured } \\
\text { interview and } \\
\text { participant observation/ } \\
\text { Without intervention }\end{array}$ & $\begin{array}{l}\text { To know the generational interrelations } \\
\text { that interfere in caring for the NBs' umbilical } \\
\text { stump. }\end{array}$ \\
\hline $\begin{array}{l}\text { A11 - Cuidando do filho } \\
\text { recém-nascido: vivência de } \\
\text { adolescentes primíparas }{ }^{(16)}\end{array}$ & $\begin{array}{l}2011 \\
\text { Brazil }\end{array}$ & $\begin{array}{l}\text { Qualitative/ } \\
8 \text { primiparous adolescent } \\
\text { mothers }\end{array}$ & $\begin{array}{l}\text { Direct non-participant } \\
\text { observation and semi- } \\
\text { structured interview/ } \\
\text { Without intervention }\end{array}$ & $\begin{array}{l}\text { To understand the experience of } \\
\text { primiparous adolescents in relation to care } \\
\text { for NBs and analyze the factors that interfere } \\
\text { in NB care by the adolescent mother. }\end{array}$ \\
\hline $\begin{array}{l}\text { A12 - Cuidado familial } \\
\text { de recém-nascidos no } \\
\text { domicílio: um estudo de } \\
\text { caso etnográfico }^{(4)}\end{array}$ & $\begin{array}{l}2011 \\
\text { Brazil }\end{array}$ & $\begin{array}{c}\text { Qualitative/18 family members } \\
\text { of NBs }\end{array}$ & $\begin{array}{l}\text { Open interview, medical } \\
\text { records and participant } \\
\text { observation/ } \\
\text { Without intervention }\end{array}$ & $\begin{array}{l}\text { To analyze the dynamics of family care for } \\
\text { NBs at home, in the city of Piraí, RJ. }\end{array}$ \\
\hline $\begin{array}{l}\text { A13 - Noninstitutional } \\
\text { births and newborn } \\
\text { care practices among } \\
\text { adolescent mothers in } \\
\text { Bangladesh }^{(17)}\end{array}$ & $\begin{array}{c}2011 \\
\text { Bangladesh }\end{array}$ & $\begin{array}{l}\text { Quantitative- demographic/ } \\
580 \text { adolescent women }\end{array}$ & $\begin{array}{l}\text { Demographic health } \\
\quad \text { survey/ } \\
\text { Without intervention }\end{array}$ & $\begin{array}{l}\text { To describe NB home care practices among } \\
\text { adolescent mothers in Bangladesh and } \\
\text { identify sociodemographic factors related } \\
\text { to prenatal care and factors associated with } \\
\text { these practices. }\end{array}$ \\
\hline 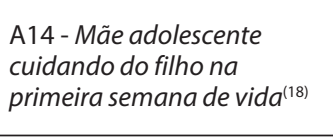 & $\begin{array}{l}2009 \\
\text { Brazil }\end{array}$ & $\begin{array}{l}\text { Qualitative/ } \\
6 \text { adolescents }\end{array}$ & $\begin{array}{l}\text { Semi-structured } \\
\text { interview and } \\
\text { participant observation/ } \\
\text { Without intervention }\end{array}$ & $\begin{array}{l}\text { To understand the experience of adolescent } \\
\text { mothers in caring for their child in the first } \\
\text { week of life. }\end{array}$ \\
\hline $\begin{array}{l}\text { A15 - General practice of } \\
\text { teenage mothers caring for } \\
\text { their children }^{(19)}\end{array}$ & $\begin{array}{l}2009 \\
\text { Brazil }\end{array}$ & $\begin{array}{c}\text { Qualitative/ } \\
6 \text { adolescent mothers }\end{array}$ & $\begin{array}{l}\text { Semi-structured } \\
\text { interview/ } \\
\text { Without intervention }\end{array}$ & $\begin{array}{l}\text { To identify and describe the popular care } \\
\text { adopted by adolescent mothers in assisting } \\
\text { their children in the first six months of life. }\end{array}$ \\
\hline $\begin{array}{l}\text { A16 - Vivência da puérpera- } \\
\text { adolescente no cuidado } \\
\text { do recém-nascido, no } \\
\text { domicílio(20) }^{(20)}\end{array}$ & $\begin{array}{l}2008 \\
\text { Brazil }\end{array}$ & $\begin{array}{l}\text { Qualitative/ } \\
15 \text { adolescent puerperal } \\
\text { women }\end{array}$ & $\begin{array}{l}\text { Semi-structured } \\
\quad \text { interview/ } \\
\text { Without intervention }\end{array}$ & $\begin{array}{l}\text { To understand how adolescent mothers } \\
\text { experience childcare at home. }\end{array}$ \\
\hline
\end{tabular}

Most of the manuscripts, 12 (75\%), were published in scientific journals in the field of nursing; 03 publications (18.8\%) were published in multidisciplinary journals in the health area and 01 (6.3\%) in the biomedical area. Three journals, namely, Revista de Enfermagem UFPE on line, Revista Texto \& Contexto Enfermagem, and Midwifery Journal published two articles each (12.5\%) on the topic under analysis, while ten journals published only one (6.3\%) study.

There is a predominance of $10(62.5 \%)$ studies with a qualitative approach, while 05 (31.3\%) were quantitative studies with statistical analysis and only 01 (6.3\%) with a mixed approach. As for participants, $100 \%$ of the publications had mothers, including primiparous women and adolescents. There were studies that also covered other family members, such as parents.

As for the place where the study was carried out, the smallest portion, 06 (37.5\%), was carried out outside Brazil. Four studies $(25 \%)$ were carried out in southeastern, $04(25 \%)$ in northeastern and $02(12.5 \%)$ in southern Brazil. No studies were found in northern and center-western Brazil. Of these, 05 (50\%) used joint accommodation as a research setting; 02 (20\%) used Basic Health Units; 02 (20\%) used a maternity unit; and 01 (10\%) used a family health unit. 
Through critical and interpretative analysis, two categories emerged, which allowed to synthesize the findings, namely: Family practices and doubts in postnatal care for newborns; and Best practices in postnatal care for newborns.

\section{Family practices and doubts in postnatal care for newborns}

$A 6^{(12)}, A 7^{(5)}, A 8^{(13)}$, and $A 10^{(15)}$, carried out in Colombia and in the countryside of the States of São Paulo, Maranhão, and Bahia, identified different post-natal care adopted by families in managing umbilical stump. This care came from popular knowledge, which included use of pure water; herbs such as marigold, chamomile, and dry cotton leaf; oils such as camphor, almonds, and castor; non-sterile utensils such as bands and coins to prevent umbilical hernia; smoke powder, chicken feather, drying powder and shoemaker's glue on the stump.

A4 ${ }^{(10)}$, conducted in India, showed that some home birth assistants used non-sterile thread to tie the umbilical cord. The mothers were advised to coat NBs' stumps with multiple applications. Therefore, their influence was highlighted by mothers as one of the common reasons for not adopting safe practices in stump care. On the other hand, A10 ${ }^{(15)}$, carried out in Brazil, identified $70 \%$ alcohol use by puerperal women, while $A 2^{(8)}$ and $A 4^{(10)}$, carried out in Nepal and India, reported dry stump care.

Regarding the NBs' bath at home, different cultural practices related to this care also emerged in the studies. A research carried out in Singapore $A 5^{(11)}$ and in the countryside of São Paulo $A 7^{(5)}$, for instance, identified failure to bath at night, baths infused with herbs and flowers, such as white rose, in addition to use of corn due to sebaceous milium and beggar's tick bath to treat jaundice.

$A 1^{(7)}$ and $A 10^{(15)}$, both performed in the countryside of Bahia, and $A 12^{(4)}$, in the countryside of Rio de Janeiro, found that families performed body hygiene in bathtubs. However, the findings of article $A 1^{(7)}$ found that the hole in the bottom of the bath remained closed and warm water was used. On the other hand, $A 10^{(15)}$ found that the orifice was open to drain the water and the puerperal woman cleaned the bathtub with alcohol.

Concerning the NBs' first bath, article $\mathrm{A} 2^{(8)}$, developed in Nepal, showed that most baths were performed 6 hours after birth, followed by a portion of baths on the second day. Furthermore, 79\% of puerperal women had their hands cleaned before handling their babies. However, $A 4^{(10)}$, from India, showed that late bath after 48 hours was given to babies by $64 \%$ of mothers and $45 \%$ were concerned with hand hygiene before handling NBs. However, under the influence of midwives, $17 \%$ bathed immediately after birth and $59 \%$ of mothers reported not considering hand hygiene necessary. Of these, $15 \%$ mentioned not having time for such a practice.

Through analysis, $A 1^{(7)}, A 5^{(11)}, A 9^{(14)}, A 11^{(16)}, A 12^{(4)}, A 14^{(18)}$, and $A 16^{(20)}$ identified the main doubts of puerperal and family members regarding to the NBs' hygiene arising from fear and insecurity of letting the baby fall into the bath and cleaning the umbilical stump. $A 11^{(16)}$, especially, reported the concern about the NBs' crying, and $A 10^{(15)}$ reported doubt about possible pain in the stump area, as well as its dryness. It is worth noting that such demands come from different regions of Brazil, in addition to other countries such as Portugal, Colombia, and Singapore, including from adolescent mothers to mothers with previous experiences in relation to motherhood.

Non-exclusive breastfeeding until 6 months of age was evidenced in $A 3^{(9)}, A 4^{(10)}, A 5^{(11)}, A 6^{(12)}, A 8^{(13)}, A 14^{(18)}$, and $A 15^{(19)} . A 3^{(9)}$, carried out in Ribeirão Preto, showed that adolescent mothers recognized the importance of breastfeeding and reported breastfeeding according to the baby's needs. However, they started adding complementary foods to their children's diets when they believed that breast milk alone was insufficient to meet nutritional needs. Research carried out in Maranhão, $A 8^{(13)}$, Paraná, $A 14^{(18)}$, and $A 15^{(19)}$ reported, regarding feeding practices, introduction of warm milk, porridge, and bottle, due to the belief that milk is weak or insufficient. $A 6^{(12)}$, applied in Colombia, identified that $64.4 \%$ of NBs were exclusively breastfed, while $35.5 \%$ received the offer of breast milk and substitutes. Of these, a group of $5 \%$ consumed milk substitutes prepared with barley water.

$A 14^{(18)}$, for instance, evidenced that all adolescent mothers breastfed their children with breast milk during the first week of life, almost all exclusively, but two started complementation. One of them was offering through a bottle, in addition to using a pacifier to help calm the child. Another mother offered tea in the bottle to prevent and relieve colic. In the same study, some puerperal women reported putting their children to burp after breastfeeding and when they did not burp, they lateralized them using a back support to avoid bronchoaspiration.

As for breastfeeding, $\mathrm{A} 3^{(9)}, \mathrm{A} 5^{(11)}, \mathrm{A} 6^{(12)}, \mathrm{A} 9^{(14)}, \mathrm{A} 12^{(4)}$, and $\mathrm{A} 14^{(18)}$ (Ribeirão Preto, Colombia, Portugal, Rio de Janeiro and Paraná) reported doubts on handle, positioning, manual milking, management of nipple fissure, inverted nipple, pain, artificial feeding and "weak milk".

Moreover, family practices relevant to the management of colic were evidenced in $A 7^{(5)}, A 8^{(13)}, A 12^{(4)}, A 14^{(18)}$, and $A 15^{(19)}$. It was included, on a recurring basis, changes in the maternal diet such as suspension of grains, citrus fruits, dairy products and fats. In addition, introduction of teas in the NBs' diet such as garlic, mint or chamomile was evidenced in $A 8^{(13)}, A 12^{(4)}$, and $A 14^{(18)} . A 12^{(4)}$ signaled physical maneuvers, in addition to seeking help from health services, relatives and religion to sort colic out.

Other cultural practices arising from intergenerational beliefs were identified in different scenarios in $A 1^{(7)}, A 4^{(10)}, A 5^{(11)}, A 7^{(5)}$, $A 8^{(13)}, A 10^{(15)}, A 12^{(4)}, A 15^{(19)}$, and $A 16^{(20)} . A 7^{(5)}$, from the countryside of São Paulo, identified that for some families, the umbilical stump must be buried next to flowers or rose bushes for the child to become a good adult or to be kept with the mother so that they can grow close. The baby cannot leave the house before the age of seven to prevent "seven-day measles", neonatal tetanus and hemorrhage from vitamin $\mathrm{K}$ deficiency.

$A 10^{(15)}$, from the countryside of Bahia, identified practices of not leaving home before seven days, in addition to not bathing in the first days and placing scissors under the pillow. In $A 7^{(5)}$, there are also religious practices as a presentation for Christian religions; blessings performed by prayers to protect children; sympathetic internet searches for children who exchange the day for the night, such as turning the baby's shirt inside out, also present in $\mathrm{A} 15^{(19)}$.

To improve the hiccup, $A 8^{(13)}$, carried out in Maranhão, reports use of red lint or rue leaf on the child's forehead. $A 15^{(19)}$, developed 
in Paraná, describes a pause in breastfeeding, a piece of wool on the forehead and a glass turned down to relieve the hiccup. It also mentioned homemade syrups, a mix of medicinal herbs, honey and sugar, when professional health care does not immediately resolve skin or flu problems.

Finally, doubts related to the prevention of diaper rash, hydration, sunbathing, sleep, diarrhea, constipation or in case of bronchoaspiration were observed in study $A 9^{(14)}$, conducted in Portugal.

\section{Good practices in postnatal care for newborns}

Concerning the best recommendations regarding care with the NBs' umbilical stump at home, $70 \%$ alcohol use was addressed in $\mathrm{A} 1^{(7)}, \mathrm{A} 8^{(13)}$, and $\mathrm{A} 10^{(15)}$, as recommended by the Brazilian Ministry of Health (MoH). A1 points out that, at the end of the bath, carried out with water and neutral soap, it is necessary to properly dry the stump and at its base apply alcohol to each diaper change, in order to accelerate the mummification and fall process. In contrast, $A 4^{(10)}$, a research carried out in India, recommended dry care, without the use of any antiseptic on the stump.

With regard to bath, $A 1^{(7)}$ mentions the importance that it occurs by spraying instead of immersion, and should use the bathtub only for support, with the hole open to drain the water containing dirt. The bathtub being used to immerse the baby with a closed orifice accumulates remains of body fluids such as urine, feces, blood, caseous vernix, which can contaminate it causing omphalitis and umbilical infections.

$\mathrm{A} 2^{(8)}$, produced in Nepal, reports that according to WHO, bathing should be delayed to 24 hours post-birth and, if this is not possible, wait at least 6 hours. A13 ${ }^{(17)}$, from Bangladesh, recommends as a safe practice that the first bath should be performed after 72 hours of birth. $A 2^{(8)}$ and $A 4^{(10)}$ mentioned the need to keep babies' eyes clean and hand hygiene with soap and water before handling the baby.

Concerning exclusive breastfeeding up to 6 months, $A 3^{(9)}, A 4^{(10)}$, $A 6^{(12)}, A 8^{(13)}, A 12^{(4)}$, and $A 15^{(19)}$ recommend this practice, according to the $\mathrm{WHO}$, as breast milk contains immunoglobulins, vitamins and nutritional elements necessary for the child's health. The value of breastfeeding within the first hour of life is also mentioned in $A 15^{(19)} . A 8^{(13)}$ recommends combating silicone nipples, in view of the increased risk of suffocation, especially during sleep, the likelihood of early weaning, in addition to being able to cause dental, speech and contamination problems.

A $14^{(18)}$ recommends carrying out vaccination schedule and follow-up consultations with the pediatrician.

In relation to the provision of care to NBs from the perspective of beliefs, family practices and experience of the adolescents themselves, $A 15^{(19)}$ observes that some of these practices are potentially harmful, considering the children's age. Thus, the appearance of infectious diseases is possible, in addition to placing exclusive breastfeeding at risk until the sixth month of life.

$A 3^{(9)}, A 4^{(10)}, A 5^{(11)}, A 7^{(5)}, A 8^{(13)}, A 9^{(14)}, A 11^{(16)}, A 12^{(4)}, A 13^{(17)}, A 14^{(18)}$, and $A 15^{(19)}$ note the need for better guidance from mothers and family members by health professionals in relation to the performance of pre and post-natal care. They meet the demands for learning about breastfeeding issues such as preventing nipple cracks and facilitating elements for the production of breast milk, as is the case exemplified in $\mathrm{A}^{(9)}$ on non-use of bottles and artificial milk and in $A 5^{(11)}$, regarding incentive for the partner and family to be present and support the puerperal woman. A16 ${ }^{(20)}$ also brings as subjects to be addressed the bodily and intimate hygiene of NBs, diaper change and care with the umbilical stump.

$A 13^{(17)}$, carried out in Bangladesh, highlights the sufficient visit to prenatal care and births attended by trained professionals significantly associated with several safe practices of care for NBs. In this sense, $A 16^{(19)}$, from São Paulo, spoke about a adolescent puerperal woman who, during the hospitalization period, was supervised and oriented in relation to baby care. Thus, she performed well in the practices of these activities during puerperium at home.

$A 16^{(19)}$ reports that the practices oriented by nursing to puerperal women satisfy their needs with regard to the care provided to the NB at home, however it was not described how they are performed. Finally, A5 ${ }^{(11)}$, carried out in Singapore, highlighted the need for the family to practice care with the NB and not only observe the performance by nursing professionals.

\section{DISCUSSION}

The transition period from motherhood to home involves the performance of usual and daily care by family members to NBs, aiming at maintaining life. With this, the concept of family care emerges, which consists of the conceptual systematization of the process apprehended and built by the family. It is defined based on family culture, intrafamily and extrafamily social interactions, throughout the family's life process and in the different stages of human life ${ }^{(4)}$.

Based on this concept and the findings of this study, it is noted that postnatal care practices developed by family members to the NB, as well as professional recommendations for carrying out these practices, vary according to the local context. This context sometimes converges and sometimes diverges from the good practices evidenced in the national and international scientific literature ${ }^{(10,12,21-27)}$.

With regard to care with umbilical stump, different care measures adopted by families in their management were identified. However, according to the WHO Clinical Guidance Standard (2013) and the Canadian Agency for Drugs and Technologies in Health (2013), dry care is the best option in developed countries, with a low neonatal mortality rate, having in view of the reduced risk of omphalitis and faster and easier access to healthcare. This technique reduces the fall time of the umbilical stump, when compared to the application of solutes ${ }^{(21-24)}$.

In underdeveloped and developing countries, on the other hand, with high rates of infection and neonatal mortality resulting from low resources and the absence of "clean birth" (aseptic), the majority being at home without the presence of a qualified professional, dry care may not be revealed as best practice. In these situations, the choice of a method based on the application of an antiseptic solution is more appropriate ${ }^{(23-24)}$.

Studies in a systematic review have generated significant evidence, suggesting that topical application of $0.5 \%$ to $4 \%$ chlorhexidine in the umbilical cord reduces neonatal mortality and omphalitis 
in the community and in primary care in developing countries ${ }^{(25)}$ like Brazil. In this regard, high-quality evidence from three studies proved that cleaning the cord with chlorhexidine compared to dry care reduces neonatal mortality and omphalitis/infections ${ }^{(26)}$.

It is worth mentioning that $70 \%$ alcohol is used in several countries, including Brazil, as recommended by the Brazilian Society of Pediatrics (Sociedade Brasileira de Pediatria, abbreviated SBP) and $\mathrm{MoH}^{(27)}$. However, according to a review study ${ }^{(24)}$, alcohol does not promote drying. It has a lesser antibacterial effect than the other antimicrobials and delays the fall of the cord, but it is a low-cost product with easy access, which generalized its use $\mathrm{e}^{(25)}$. In the case of toxic effects, $70 \%$ alcohol can cause cutaneous hemorrhagic necrosis and present serum levels with toxicity, in contrast to chlorhexidine, which has systemic absorption without toxic effects in term babies ${ }^{(28-29)}$. Such evidence reinforces the need for the review and standardization of therapeutic conducts and professional guidance regarding the management of the umbilical stump in maternity wards and in the social and family context, including in Brazil. Currently, application of chlorhexidine is considered a recommended practice for low- and middle-income countries, however it is not yet widespread and consolidated.

Additional precautions include keeping the stump dry and uncovered and not applying contaminated home substances. Caregiver's hand hygiene measures when handling the stump or changing diapers and frequent changing of them after urination or evacuation are essential and beneficial measures in reducing umbilical stump infections s $^{(29-30)}$.

Concerning the NBs' bath, this is a routine postnatal care that normally follows a cultural tradition, with the objective of removing skin residues and reducing colonization ${ }^{(31)}$. Regarding this care, different cultural practices were also highlighted in the studies, on the other hand, recommendations based on consensus are scarce.

The NBs' first bath generates many controversies regarding the timing of their performance. A study showed occurrence of hypothermia in 60 NBs (40.3\%) of the 149 participating babies, by checking the axillary temperature before and after bathing between the first four hours of life. It was suggested that bathing in this time interval may interfere with thermoregulation and should be postponed for a few more hours ${ }^{(31-32)}$.

According to WHO and SBP, this care must be performed after there is thermal and cardiorespiratory stability, not before 6 hours of life. The immersion bath is the most suitable, with warm water (ideal temperature between $35-36^{\circ} \mathrm{C}$ ), allowing less heat loss and offering more comfort to the baby. Head and neck should not be immersed ${ }^{(28)}$, which differs from studies that indicate the sprinkler bath, aiming mainly at preventing omphalitis ${ }^{(7)}$.

Baby hygiene products can be carried out without surfactants, which are known as "syndets". These bar or liquid soaps are based on synthetic detergents that are neutral or slightly acidic, with a $\mathrm{pH}$ less than 7, which remove dirt and eliminate less lipids and water from the NBs' skin. They therefore reduce the risk of dryness and irritability. Cleaning agents based on alkaline soaps with a $\mathrm{pH}$ greater than 10 are more likely to irritate the skin, when compared to synthetic ones, even glycerin soaps can remove water from the skin causing dryness ${ }^{(28,32-33)}$. This reinforces the need for specific knowledge and guidance by health professionals.
It is worth mentioning that the Brazilian $\mathrm{MoH}$ also emphasizes the importance of hand hygiene with soap and water and alcoholic solution before and after handling NBs as an important preventive measure for infection control ${ }^{(27)}$. The aforementioned was devalued by some groups in the investigations analyzed in this study.

For WHO, the American Academy of Pediatrics (AAP), $\mathrm{MoH}$, and SBP, breastfeeding should be started in the delivery room in the first hour of life. It is recommended that it be maintained exclusively until the age of six months and supplemented until the age of two or more. This is due to the fact that breastfeeding is a natural strategy in addition to nutrition therefore it is also a bonding and protection tactic for the child. It is an effective intervention to reduce child morbidity and mortality, especially due to infectious diseases, strengthening the organism and reducing the appearance of gastrointestinal and respiratory diseases. There are numerous short- and long-term benefits for the child, the breastfeeding woman, the family and society ${ }^{(34-37)}$.

Women's insecurity about everyday issues, such as the production of quality breast milk in sufficient quantity for the baby and the child's crying, associated with hunger, among other aspects, are pointed out as possible causes that justify culturally rooted practices such as early introduction of other foods. That is, before the baby's six months of life, there are artificial nipples such as pacifiers and bottles or even the interruption of breastfeeding $^{(38)}$, as indicated in the research, which has harmful effects on breastfeeding and health of child.

A survey carried out with primiparous and multiparous women in the provision of care to the NB highlighted that both groups had difficulties related to NB care similar to those found in this review, such as the correct grip, handling of fissures and nipple engorgement, and breast milking. However, doubts regarding the inverted nipple, artificial feeding and "weak milk" were not mentioned, according to the findings of this review. In addition, there were doubts about the umbilical stump in relation to cleaning, what to put on it and the fear of handling it, in addition to difficulties with diaper rash that also converge with the demands found in the present study ${ }^{(39)}$. Such findings reinforce the need for health education activities, from a dialogical perspective, in all nursing actions in monitoring pregnancy, childbirth, puerperium, and home care.

It is observed, therefore, that primiparous and multiparous women from different age groups and different cultures have similar difficulties in caring for NBs. This is due to the fact that each maternity hospital is a unique experience, lived in a unique way, regardless of previous maternal experiences ${ }^{(39)}$. Therefore, all women need support and counseling.

Doubts about crying are common, considering that it is a common symptom in the first three months of life and responsible for about $20 \%$ of pediatric consultations. Although it is mostly of benign etiology, it is often a source of concern ${ }^{(38,40)}$.

It should be noted that studies present sufficient evidence that sleeping in the supine position reduces the occurrence of sudden infant death. However, a study carried out in the South of Brazil shows that only twenty percent of the mothers interviewed expressed the intention to put their NBs to sleep on their backs ${ }^{(41)}$. This signals that there is a need to strengthen postnatal 
care through effective guidance and monitoring in health units and home visits.

Some practices evidenced in this study, such as placing objects in the navel, such as coins and bands, tea use to eliminate colic and the need to offer other foods or liquids to NBs before 6 months converge with the findings of another study. Culturally, these practices are still employed, although they are not recommended, given the evidence of the lack of benefit for babies, and even if reduced, they lead to error in caring for babies, putting them at risk ${ }^{(42)}$.

There will always be cultural and family influences and these must be respected, however, it is necessary to combine this knowledge with good practices in postnatal care for NBs recommended by $\mathrm{WHO}, \mathrm{MoH}$ and other recognized bodies, strengthening actions that are safe and deconstructing those that pose a risk to the child's health. Therefore, dialogue between popular knowledge and scientific knowledge is revealed as an indispensable act ${ }^{(43)}$ so that, thus, a quality, safe and autonomous care practice is achieved.

In view of the findings presented, it is necessary to invest in educational health practices from pre to post-natal, especially in relation to daily care for NBs, as mentioned above. In this way, the nurse can play an elementary role, as he has the opportunity to participate in the monitoring and contribute as an educating agent during all phases of this process, minimizing the difficulties faced by puerperal women and families with $\mathrm{NBs}^{(39,44)}$.

\section{Study limitations}

It should be noted that, although the objective proposed by the study has been achieved, there are some limitations. The studies aggregated in this review refer to diverse cultural, social and economic realities and contexts, which reflect in different actions and policies, which made it difficult to compare practices and generalize the findings. Furthermore, they do not encompass all postnatal care practices to be developed in the social-family environment. Therefore, there is a need for further studies in this area that use homogeneous methodologies and representative samples in order to achieve a greater degree of evidence.

\section{Contributions to nursing, health, and public policies}

Compiling the postnatal care practices of NBs in the context of the family, it is expected that the study will contribute to the area of health and nursing, since it made it possible to identify the practices and doubts of the families, in addition to discussing the best recommendations of scientific literature. This may contribute to the construction of guidance plans with families during the prenatal period, in the discharge process in the maternity ward and in the post-discharge period in different contexts.

Moreover, it is noteworthy that family members are often exposed to divergent orientations from different professionals or institutions. Therefore, qualification of the instructions, based on the best available evidence, can strengthen the security in carrying out postnatal care and the trust between families and health professionals.

Finally, it is expected that the present study will stimulate new investigations in order to fill the gaps discovered, in addition to promoting a critical reflection on the need for professionals to rethink their educational activities, mainly in relation to the construction of a scientifically based guidance plan and new health educational technologies. Family members are expected to take care of their babies at home with quality, autonomy and safety, thus aiming at health promotion, as well as a significant reduction in neonatal morbidity and mortality from preventable causes.

\section{FINAL CONSIDERATIONS}

The findings of the present study point to several care practices linked to a cultural perspective, where the forms of care are passed on to generations. However, in some cases, such practices differ from scientific recommendations, which can generate risks to the health of NBs.

Therefore, it is essential to consolidate educational programs with pregnant women, puerperal women, parents and family members that address safe practices in postnatal care for NBs in both primary and hospital care, making the most of the contact established with these family members. Thus, there is a glimpse of improvements in the quality of care offered and the reduction of preventable neonatal deaths in different social and family contexts.

It is worth highlighting the need for individualized planning, carried out by nurses, taking into account issues related to family biopsychosociocultural spheres. Moreover, it is necessary for nurses to be guided by the actions that are their responsibility in the context of primary care, carrying out home visits as soon as the mother-baby binomial returns from the maternity hospital, to identify difficulties and inadequacies in care and to promote the necessary changes.

Finally, further research on good practices in the postnatal care of NBs is necessary, in order to qualify the transition process from professional care to family care, envisioning healthy and harmonious child development, including the review of guidelines and conduct in the area.

\section{REFERENCES}

1. Brizuela V, Tunçalp Ö. Global initiatives in maternal and newborn health. Obstet Med. 2017;10:221-52. doi: 10.1177/1753495X16684987

2. Müller EB, Zampieri MFM. Divergências em relação aos cuidados com o recém-nascido no centro obstétrico. Esc Anna Nery. 2014;18(2):24756. doi: 10.5935/1414-8145.20140036

3. Bhutta ZA, Das JK, Bahl R, Lawn, JE, Salam RA, Paul VK, et al. Can available interventions end preventable deaths in mothers, newborn babies, and stillbirths, and at what cost? Lancet. 2014;26;384(9940):347-70. doi: 10.1016/S0140-6736(14)60792-3

4. Leandro JS, Christoffel MM. Cuidado familial de recém-nascidos no domicílio: um estudo de caso etnográfico. Texto Contexto Enferm. 2011;20(spe):223-31. doi: 10.1590/S0104-07072011000500028 
5. Baraldi NG, Praça NS. Práticas de cuidado do recém-nascido baseadas no contexto de vida da puérpera. Ciênc Cuid Saúde. 2013;12(2):282-9. doi: 10.4025/cienccuidsaude.v12i2.19596

6. Souza LMM, Maeques-Vieira CMA, Severino SSP, Antunes AV. A metodologia de revisão integrativa da literatura de enfermagem. Rev Invest Enferm [Internet]. 2017 [cited 2019 Jun 06];Ser.II(21):17-26. Available from: https://www.researchgate.net/ publication/321319742_Metodologia_de_Revisao_Integrativa_da_Literatura_em_Enfermagem

7. Linhares EF, Marta FEF, Dias JAA, Santos MCQ. Influência geracional familiar no banho do recém-nascido e prevenção de onfalites. Rev Enferm UFPE. 2017;11(11):4678-86. doi: 10.5205/reuol.11138-99362-1-SM.1111sup201718

8. Karkee R, Khanal V. Postnatal and neonatal care after home birth: a community-based study in Nepal. Women Birth. 2016;29(3):39-43. doi: 10.1016/j.wombi.2015.10.003

9. Monteiro JCS, Dias FA, Stefanello J, Reis MCG, Nakano MAS, Gomes-Sponholz FA. Breast feeding among Brazilian adolescents: practice and needs. Midwifery. 2014;30(3):359-63. doi: 10.1016/j.midw.2013.03.008

10. Sinha LN, Kaur P, Gupta R, Dalpath S, Goyalc V, Murhekar M. Newborn care practices and home-based care programme: Mewat, Haryana, India, 2013. W Pac Surv Resp J. 2014;5(3):22-9. doi: 10.5365/WPSAR.2014.5.1.006

11. Ong SF, Chan WCS, Shorey S, Chong YS, Klainin-Yobas P, He HG. Postnatal experiences and support needs of first-time mothers in Singapore: a descriptive qualitative study. Midwifery. 2014;30(6):772-8. doi: 10.1016/j.midw.2013.09.004

12. Rico DAP. Adopción de prácticas saludables en puérperas adolescentes. Rev Cuid. 2013;4(1):450-8. doi: 10.15649/cuidarte.v4i1.4

13. Jesus ACP, Bandeira LPL, Araújo MFM, Gubert FA, Vieira NFC, Rebouças CBA. Popular knowledge in care of the newborn with focus on health promotion. Rev pesqui cuid fundam (Online). 2013; 5(2):3626-5. doi: 10.9789/2175-5361.2013v5n2p3626

14. Santos R, Cardoso B, Duarte V, Henriques CMG, Jorge S, Alexandre J. Dificuldade dos pais no cuidar do recém-nascido. Medwave. 2012;12(4):e5408. doi: 10.5867/medwave.2012.04.5408

15. Linhares EF, Silva LWS, Rodrigues VP, Araújo RT. Influência intergeracional no cuidado do coto umbilical do recém-nascido. Texto Contexto Enferm. 2012;21(4):828-36. doi: 10.1590/S0104-07072012000400013

16. Morais AC, Campos CSC. Cuidando do filho recém-nascido: vivência de adolescentes primíparas. Rev Enferm UFPE. 2011;5(10):2406-14. doi: 10.5205/reuol.2133-15571-1-LE.0510201110

17. Rahman M, Haque SE, Zahan S, Islam O. Noninstitutional births and newborn care practices among adolescent mothers in Bangladesh. J Obstet Gynecol Neonatal Nurs. 2011;40(3):262-73. doi: 10.1111/j.1552-6909.2011.01240.x

18. Tomeleri KR, Marcon SS. Mãe adolescente cuidando do filho na primeira semana de vida. Rev bras Enferm. 2009;62(3):355-61. doi: 10.1590/ S0034-71672009000300004

19. Tomeleri KR, Marcon SS. General practice of teenage mothers caring for their children. Acta Paul Enferm. 2009;22(3):272-80. doi: 10.1590/ S0103-21002009000300006

20. Bergamaschi SFF, Praça NS. Vivência da puérpera-adolescente no cuidado do recém-nascido, no domicílio. Rev Esc Enferm USP. 2008;42(3):454-60. doi: 10.1590/S0080-623420080000300006

21. World Health Organization (WHO). WHO recommendations on postnatal care of the mother and newborn. Geneva: WHO; 2013.

22. Canadian Agency for Drugs and Technologies in Health. Optimal inhospital umbilical cord care for newborns: clinical evidence and guidelines. Ottawa: CADTH; 2013.

23. Barbosa M, Moreira S, Ferreira S. Desinfeção do cordão umbilical: revisão baseada na evidência. Rev Port Med Geral Fam. 2017;33(1):41-7. doi: 10.32385/rpmgf.v33i1.12022

24. Luís S, Costa GA, Casteleiro C. Boas práticas nos cuidados ao coto umbilical: um estudo de revisão. Millenium [Internet]. 2014 [cited 2019 Mar 08];47:33-46. Available from: http://www.ipv.pt/millenium/Millenium47/4.pdf

25. Imdad A, Bautista RM, Senen KA, Uy ME, Mantaring JB 3rd, Bhutta ZA. Umbilical cord antiseptics for preventing sepsis and death among newborns. Cochrane Database Syst Rev. 2013; 5: CD008635. doi: 10.1002/14651858.CD008635.pub2

26. Sinha A, Sazawal S, Pradhan A, Ramji S, Opiyo N. Chlorhexidine skin or cord care for prevention of mortality and infections in neonates. Cochrane Database Syst Rev. 2015;3:CD007835. doi: 10.1002/14651858.CD007835.pub2

27. Ministério da Saúde (BR). Atenção à saúde do recém-nascido: guia para os profissionais de saúde. 2.ed. Brasília: Ministério da Saúde; 2014.

28. Ness MJ, Davis DM, Carey WA. Neonatal skin care: a concise review. Int J Dermatol. 2013;52(1):14-22. doi: 10.1111/j.1365-4632.2012.05687.x

29. Carvalho VM, Markus JR, Abagge KT, Giraldi S, Campos TB. Consenso de cuidado com a pele do recém-nascido. São Paulo: Sociedade Brasileira de Pediatria; 2015.

30. Ribeiro SCSS, Rocha RS, Jacob LMS, Jorge HMF, Mafetoni RR, Pimenta CJL. Atividade educativa para a promoção do cuidado com o recémnascido. Rev Saúde Pesq. 2018;11(3):545-53. doi: 10.17765/2176-9206.2018v11n3p545-553

31. Ruschel LM, Pedrini DB, Cunha MLC. Hipotermia e banho do recém-nascido nas primeiras horas de vida. Rev Gaúcha Enferm. 2018;39:e20170263. doi: 10.1590/1983-1447.2018.20170263

32. Pinto MCPF, Oliveira MLF, Bedendo, J. Cuidados com a pele do recém-nascido: um desafio para a equipe da unidade de terapia intensiva neonatal. Rev Uningá Rev[Internet]. 2018 [cited 2019 Jun 06] 16(1):2178-571. Available from: http://revista.uninga.br/index.php/uningareviews/article/view/1459 
33. Fernandes JD, Machado MCR, Oliveira ZNP. Prevenção e cuidados com a pele da criança e do recém-nascido. An Bras Dermatol. 2011;86(1):102-10. doi: 10.1590/S0365-05962011000100014

34. Victora CG, Horta BL, Mola CL, Quevedo L, Pinheiro RT, Gigante DP, et al. Association between breastfeeding and intelligence, educational attainment, and income at 30 years of age: a prospective birth cohort study from Brazil. Lancet Glob Health. 2015;3(4)199-205. doi: $10.1016 / \mathrm{S} 2214-109 \times(15) 70002-1$

35. Victora CG, Bahl R, Barros AJD, França GVA, Hoton S, Krasevec J et al. Breastfeeding in the 21st century: epidemiology, mechanisms, and lifelong effect. Lancet. 2016;387(10017):475-90. doi: 10.1016/S0140-6736(15)01024-7

36. Ministério da Saúde (BR). Saúde da criança: aleitamento materno e alimentação complementar. 2. ed. Brasília: Ministério da Saúde; 2015.

37. Al-Sagarat AY, Yaghmour G, Moxham L. Intentions and barriers toward breastfeeding among Jordanian mothers: a cross sectional descriptive study using quantitative method. Women Birth. 2017;30(4):152-7. doi: 10.1016/j.wombi.2016.11.001

38. Marques ES, Cotta RMM, Priore SE. Mitos e crenças sobre o aleitamento materno. Ciênc Saúde Colet. 2011;16(5):2461-8. doi: 10.1590/ S1413-81232011000500015

39. Munhoz NT, Schmdt KT, Fontes KB. Dificuldades vivenciadas por puérperas no cuidado domiciliar com o recém-nascido. Rev Enferm UFPE. 2015;9(3):7516-23. doi: 10.5205/reuol.7049-61452-1-ED.0903supl201503

40. Halpern R, Coelho R. Excessive crying in infants. J Pediatr. 2016;92(Supl1):40-5. doi: 10.1016/j.jped.2016.01.004

41. Cesar JA, Acevedo JD, Kaczan CR, Venzo JCP, Costa LR, Silva LCM, Neumann NA. Intenção das mães em colocar o bebê para dormir em decúbito dorsal: um estudo de base populacional. Ciênc Saúde Colet. 2018;23(2):501-8. doi: 10.1590/1413-81232018232.20732015

42. Gomes ALM, Rocha CR, Henrique DM, Santos MA, Silva LR. Conhecimentos de familiares sobre os cuidados com recém-nascidos. Rev Rene. 2015;16(2):258-65. doi: 10.15253/2175-6783.2015000200016

43. Junges JR, Barbiani R, Ávila SN, Fernandes RBP, Lima MS. Saberes populares e cientificismo na estratégia saúde da família: complementares ou excludentes? Ciênc Saúde Colet. 2011;16(11):4327-35. doi: 10.1590/S1413-81232011001200005

44. Lucena DBA, Guedes ATA, Cruz TMAV, Santos NCCB, Collet N, Reichert APS. Primeira semana saúde integral do recém-nascido: ações de enfermeiros da Estratégia Saúde da Família. Rev Gaúcha Enferm. 2018;39:e2017-0068. doi: 10.1590/1983-1447.2018.2017-0068 